\title{
Karakteristik Kepribadian, Harga Diri dan Gaya Hidup Hedonisme Pada Mahasiswa Konsumen Starbucks
}

\author{
Teguh Lesmana*, Rudi Santoso \\ Program Studi Psikologi Fakultas Ilmu Sosial dan Humaniora Universitas Bunda Mulia \\ e-mail : "teguhlesmana73@gmail.com
}

\begin{abstract}
Coffee consumption of Indonesian people tends to increase over the past few years. Coffee drinking activity is now a lifestyle for spending money and to be able to keep up with the times by drinking at a famous coffee shop. Students especially prefer to do this activity to find a place together to spend their time having fun when at the mall. The purpose of this study was to determine the relationship between personality traits and self-esteem with hedonistic lifestyle on Starbucks consumer in Jakarta. The participants in this study consisted of 390 students who had visited Starbucks. Research participants were asked to fill out the Big Five Inventory-10 (BFI-10) questionnaire and Rosenberg self-esteem scale questionnaire that had been adapted to Indonesian, as well as the scale of the hedonistic lifestyle. The results showed that there was a significant negative relationship between self-esteem and hedonistic lifestyle, while conscientiousness personality traits had a significant positive relationship with the hedonistic lifestyle. This result explains that students can have a Hedonistic lifestyle when they do not have a positive assessment of themselves. Thus the tendency of coffee consumption based on the hedonism lifestyle is likely to be influenced by self-esteem and personality possessed.
\end{abstract}

Keywords: Personality Traits, Self-esteem, Hedonistic Life-Style, Starbucks Consumer

Abstrak. Konsumsi kopi orang Indonesia cenderung mengalami peningkatan selama beberapa tahun terakhir. Aktivitas minum kopi sekarang menjadi gaya hidup untuk membelanjakan uang dan untuk dapat mengikuti perkembangan zaman dengan minum di kedai kopi yang ternama. Mahasiswa khususnya lebih mungkin melakukan aktivitas ini ketika ingin mencari tempat berkumpul bersama temannya untuk menghabiskan waktu bersenang-senang di mal. Tujuan dari penelitian ini adalah untuk mengetahui hubungan antara karakteristik kepribadian dan harga diri dengan gaya hidup hedonisme pada mahasiswa konsumen Starbucks di Jakarta. Partisipan dalam penelitian ini terdiri atas 390 orang mahasiswa yang pernah mengunjungi Starbucks. Partisipan penelitian diminta untuk mengisi kuesioner Big Five Inventory-10 (BFI-10) dan Rosenberg self-esteem scale yang sudah diadaptasi ke bahasa Indonesia, serta skala gaya hidup hedonisme. Hasil penelitian menunjukkan bahwa terdapat hubungan negatif yang signifikan antara harga diri dengan gaya hidup hedonisme, sedangkan pada karakteristik kepribadian ditemukan kepribadian conscientiousness memiliki hubungan positif yang signifikan dengan gaya hidup hedonisme. Hasil ini menjelaskan bahwa mahasiswa dapat lebih memiliki gaya hidup hedonisme ketika tidak memiliki penilaian positif terhadap dirinya. Dengan demikian kecenderungan konsumsi kopi yang dilandasi oleh gaya hidup hedonisme kemungkinan dapat dipengaruhi oleh harga diri dan kepribadian yang dimiliki.

Kata kunci: Karakteristik Kepribadian, Harga Diri, Gaya Hidup Hedonisme, Konsumen Starbucks 
Menurut Soedargo (dalam Idris, 2017) pertumbuhan konsumsi kopi di Indonesia selalu melebihi angka $8 \%$ setiap tahunnya, dimana pertumbuhan ini didorong oleh munculnya kedai-kedai kopi di beberapa daerah yang ada di Indonesia. Berdasarkan data Asosiasi Eksportir Kopi Indonesia (AEKI) konsumsi kopi di Indonesia terus mengalami peningkatan selama 4 tahun terakhir dan hasil tersebut terungkap dari survey terkait kebutuhan kopi yang naik sebesar 36\% sejak tahun 2010 hingga 2014 (Rikang \& Dharma, 2014). Herlyana (2012) menjelaskan bahwa meminum kopi bagi masyarakat Indonesia sudah menjadi kebiasaan sehari-hari, kemudian pada saat sekarang ini jumlah penikmat kopi yang ada di Indonesia sangat banyak dan sudah tidak terhitung jumlahnya, dimana penikmat kopi tersebut tidak hanya dinikmati oleh orang dewasa saja tetapi juga dinikmati oleh remaja dan bahkan manula. Berdasarkan data dari Financial Times (dalam Maharani, 2018) diketahui bahwa jumlah kedai kopi artisan dan gerai kopi di Indonesia meningkat dua kali lipat dalam lima tahun terakhir. Menurut Moelyono (dalam Prodjo, 2016), kedai kopi artisan adalah kedai kopi yang menawarkan satu jenis kopi untuk pembeli dan memiliki proses penyajian serta dekorasi kedai yang menarik sehingga digemari dan menjadi tren di kalangan masyarakat Indonesia. Menurut Hadijah (2017), menjamurnya kedai kopi di beberapa wilayah kota besar di Indonesia dapat mengindikasikan bahwa keberadaan kopi di Indonesia menjadi populer dan menjadi bagian dari gaya hidup sebagian besar masyarakat Indonesia saat ini.

Salah satu kedai kopi yang mengalami banyak perkembangan dengan jumlah gerai yang terus bertambah di Indonesia adalah Starbucks (Laucereno, 2018). Menurut Farida (2019), saat ini total gerai Starbucks di 25 kota yang ada di Indonesia terdapat sebanyak 378 gerai dan hal ini terjadi karena Starbucks melihat potensi kopi Indonesia dapat terus berkembang menjadi salah satu komoditas kopi unggulan di dunia. Lebih lanjut dalam perkembangannya, Starbucks juga telah membuka gerai terbesar kedua di dunia yang terletak di Bali dan gerai ini merupakan satu di antara 185 gerai terbaik Starbucks di dunia (Bella, 2019). Menurut Putlia (2018), maraknya perkembangan kedai kopi di Indonesia membuat baik merek global maupun lokal turut bersaing untuk meraih posisi di benak konsumen, dan berdasarkan penelitian yang telah dilakukan pada 20 mahasiswa aktif dari 
beberapa universitas yang ada di Jakarta, diketahui bahwa satu merek kedai kopi yang paling sering disebut adalah Starbucks. Pada penelitian tersebut (Putlia, 2018), diketahui bahwa mahasiswa yang merupakan konsumen Starbucks telah masuk dalam konsumerisme dan memiliki motivasi hedonisme dengan berperilaku konsumtif dan secara tidak langsung diperdaya serta terjebak pada fetisisme komoditas. Perilaku konsumtif ini mengarah pada gaya hidup glamor, boros dan perasaan senang mengeluarkan uang untuk mendapatkan barang yang sedang populer agar tidak ketinggalan zaman. Secara umum mahasiswa menyadari perilaku konsumtif merupakan perilaku negatif, namun keinginan untuk diakui dan perasaan senang ketika dapat membeli produk Starbucks menyebabkan mahasiswa sulit menahan diri untuk tidak menjadi konsumtif.

Penelitian serupa juga dilakukan oleh $\mathrm{Ng}$ (2015), yang menemukan bahwa Starbucks dapat menjadi katalis untuk gaya hidup hedonisme bagi pelajar, hal ini dikarenakan ketika pelajar dapat membeli minuman di Starbucks maka akan muncul perasaan puas karena mendapatkan pengakuan dari temannya di media sosial dan dianggap sebagai bagian dari kelompok sosial yang memiliki kelas tinggi. Selain itu, dalam penelitian yang dilakukan oleh Ng (2015) tersebut juga dijelaskan bahwasanya keinginan para pelajar untuk mengikuti tren yang ada dan tidak ketinggalan zaman menjadi motif dari para pelajar untuk mau membeli minuman yang memiliki harga mahal meski masih belum mandiri secara finansial. Menurut Armstrong dan Kotler (2015), gaya hidup hedonisme adalah suatu pola hidup yang aktivitasnya untuk mencari kesenangan hidup, seperti lebih banyak menghabiskan waktu di luar rumah, lebih banyak bermain, senang pada keramaian kota, senang membeli barang mahal yang disukai, serta selalu ingin menjadi pusat perhatian.

Segmentasi yang mengikuti gaya hidup hedonisme salah satunya adalah pada diri anak muda atau remaja (Palinoan, 2017). Para pelajar atau mahasiswa yang umumnya masih berada pada usia muda atau remaja dapat mengikuti gaya hidup hedonisme, yang mana gaya hidup hedonisme pada pelajar atau mahasiswa tersebut disebabkan oleh adanya rasa ingin mendapatkan pengakuan dari lingkungan sekitarnya (Yuliyasinta \& Edwina, 2017). Rasa pengakuan ini dapat berhubungan dengan bagaimana harga diri seseorang, hal 
ini didukung oleh penelitian yang dilakukan oleh Hartati dan Setyawan (2010), yang menemukan bahwa harga diri memiliki hubungan yang signifikan dengan kecenderungan gaya hidup hedonisme pada mahasiswa. Dengan demikian, maka dapat dilihat bahwa harga diri dapat berperan dalam menentukan gaya hidup hedonisme pada mahasiswa.

Selain harga diri, faktor kepribadian juga menyebabkan seseorang memiliki gaya hidup hedonisme. Hal ini sejalan dengan penelitian yang dilakukan oleh Ksendzova, Iyer, Hill, Wojcik, dan Howell (2015), yang meneliti mengenai karakteristik kepribadian berdasarkan teori Big Five personality dengan perilaku hedonisme, dimana dari hasil penelitian tersebut ditemukan bahwa seseorang dengan perilaku hedonisme yang maladaptif memiliki kepribadian neuroticism yang tinggi dan memiliki kepribadian agreeableness dan conscientiousness yang rendah. Dengan demikian, berdasarkan beberapa temuan dari penelitian yang dilakukan sebelumnya, terlihat bahwa baik harga diri maupun kepribadian dapat memainkan peran dalam kecenderungan gaya hidup hedonisme. Oleh karena itu penelitian ini dilakukan untuk mengetahui peran kepribadian dan harga diri terhadap gaya hidup hedonisme pada mahasiswa konsumen Starbucks. Starbucks sendiri dipilih dikarenakan Starbucks merupakan kedai kopi yang paling sering dikunjungi dan paling dikenal oleh mahasiswa serta motivasi mahasiswa cenderung mengarah ke gaya hidup hedonis ketika mengkonsumsi kopi Starbucks, yakni ingin mendapatkan pengakuan dari lingkungan sosialnya dan ingin mendapat kepercayaan diri (Ng, 2015; Putlia, 2018).

Berdasarkan penjabaran sebelumnya, maka penelitian ini dilakukan dengan harapan dapat memberikan informasi yang dapat dijadikan sumber referensi bagi penelitian selanjutnya yang tertarik ingin meneliti mengenenai fenomena yang sama. Tujuan dari penelitian ini adalah untuk mengetahui hubungan karakteristik kepribadian dan harga diri dengan gaya hidup hedonisme pada mahasiswa konsumen Starbucks. Hipotesis dalam penelitian ini terdiri atas:

H1: Harga diri memiliki hubungan signifikan terhadap gaya hidup hedonisme pada mahasiswa konsumen Starbucks.

H2: Karakteristik kepribadian memiliki hubungan signifikan terhadap gaya hidup hedonisme pada mahasiswa konsumen Starbucks. 


\section{Metode}

\section{Partisipan}

Partisipan dalam penelitian ini adalah 390 orang mahasiswa yang berusia 18-24 tahun dan merupakan pengunjung Starbucks di Jakarta serta sudah pernah mengkonsumsi kopi di Starbucks. Metode sampling yang digunakan dalam penelitian ini adalah convenience sampling. Dari 390 partisipan penelitian, 285 orang di antaranya $(73,08 \%)$ berjenis kelamin perempuan. Peneliti menyebarkan kuesioner secara langsung dengan memberikan kuesioner kepada para mahasiswa yang sedang berada di Starbucks dan juga menyebarkan kuesioner secara online melalui berbagai aplikasi messenger seperti Line, Whatsapp, Instagram, hingga media sosial seperti Facebook. Tujuan peneliti menyebarkan kusioner secara online adalah agar data dapat terkumpul sebanyak mungkin dan dapat mengantisipasi keterbatasan waktu dan tempat dalam mengumpulkan data.

Penelitian ini merupakan penelitian kuantitatif korelasional yang bertujuan untuk menguji hubungan antara dua variabel. Variabel-variabel dalam penelitian ini terdiri atas karakteristik kepribadian, harga diri, dan gaya hidup hedonisme pada konsumen Starbucks. Alat ukur karakteristik kepribadian, harga diri, dan gaya hidup hedonisme dibuat dalam bentuk skala likert yang menghasilkan data interval dengan alat ukur karakteristik kepribadian terdiri dari skala 1-5 sedangkan alat ukur harga diri dan gaya hidup hedonisme terdiri dari skala 1-4.

\section{Instrumen penelitian}

Karakteristik kepribadian diukur dengan skala Big Five Inventory-10 (BFI-10) milik Rammstedt dan John (2006) yang telah diadaptasi ke dalam bahasa Indonesia dan sudah melalui proses uji coba. Alat ukur ini terdiri dari 10 item dan hasil uji coba menggunakan test-retest reliability dengan rentang waktu 15 hari didapatkan konsistensi hasil antara pengukuran pertama dan kedua dengan koefisien korelasi yang berkisar antara 0,895 - 0,977 (sig $\mathrm{p}=0,000<0,01)$ pada masing-masing karakter. Test-retest reliability digunakan karena jumlah item yang terlalu sedikit pada masing-masing aspek untuk pengukuran karakteristik kepribadian dalam alat ukur short form menyebabkan tidak cocok untuk dilakukan pengujian reliabilitas dengan menggunakan metode reliabilitas konsistensi internal, oleh karena itu yang digunakan adalah metode reliabilitas pengetesan ulang (test-retest). 
Hasil uji coba BFI-10 dapat dilihat pada

Tabel 1.

Tabel 1.

Hasil Reliabilitas Test-Retest BFI-10

\begin{tabular}{cc}
\hline $\begin{array}{c}\text { Karakteristik } \\
\text { Kepribadian }\end{array}$ & $\begin{array}{c}\text { Nilai r (Koefisien } \\
\text { Korelasi) Tes 1 \& 2 }\end{array}$ \\
\hline Openness to Experience & $0,970^{* *}$ \\
Conscientiousness & $0,895^{* *}$ \\
Extraversion & $0,924^{* *}$ \\
Agreeableness & $0,977^{* *}$ \\
\hline Neuroticism & $0,945^{* *}$ \\
\hline
\end{tabular}

${ }^{* *}$ Correlation is significant at 0,01 level (2-tailed)

Pengukuran harga diri dilakukan dengan menggunakan Rosenberg SelfEsteem Scale (Rosenberg, 1965) yang telah diadaptasi ke dalam bahasa Indonesia dan sudah melalui proses uji coba. Alat ukur Rosenberg Self-Esteem Scale terdiri dari 10 item dan hasil uji coba menunjukkan skor Cronbach's Alpha sebesar 0,864.

Pengukuran alat ukur gaya hidup hedonisme diukur dengan skala gaya hidup hedonisme yang disusun berdasarkan konsep dari teori gaya hidup yang menggunakan AIO (activity, interest, opinion) model dari Blackwell et al. (2012). Alat ukur gaya hidup hedonisme awalnya terdiri atas 48 item, namun setelah melalui proses uji coba hanya tersisa 39 item yang valid dan memiliki Cronbach's Alpha sebesar 0,893 .

\section{Analisis Data}

Setelah data diperoleh, peneliti kemudian melakukan pengujian secara statistik untuk menguji hubungan antara variabel-variabel penelitian. Terdapat dua kali pengujian, yakni (1) pengujian hubungan antara harga diri dan gaya hidup hedonisme, dan (2) pengujian hubungan antara karakteristik kepribadian dan gaya hidup hedonisme. Teknik analisis statistik yang peneliti gunakan adalah uji korelasi Spearman.

\section{Hasil}

Berdasarkan hasil pengambilan data mengenai lama menghabiskan waktu di Starbucks, diketahui sebagian besar partisipan dapat menghabiskan waktu lebih dari 1 jam ketika berada di Starbucks, hal ini menandakan sebagian besar partisipan cenderung menikmati waktunya di Starbucks. Data lengkap mengenai persentase lama waktu yang dihabiskan dapat di Tabel 2 berikut:

Tabel 2

Persentase Lama Menghabiskan Waktu di Starbucks

\begin{tabular}{ccc}
\hline $\begin{array}{c}\text { Lama Menghabiskan } \\
\text { Waktu di Starbucks }\end{array}$ & $\begin{array}{c}\text { Frekuen } \\
\text { si }\end{array}$ & $\begin{array}{c}\text { Persen } \\
(\%)\end{array}$ \\
\hline Kurang dari 30 menit & 27 & $6.92 \%$ \\
30 menit & 35 & $8.98 \%$ \\
1 jam & 92 & $23.59 \%$ \\
Lebih dari 1 jam & 236 & $60.51 \%$ \\
\hline
\end{tabular}




\begin{tabular}{ccc}
\hline $\begin{array}{c}\text { Lama Menghabiskan } \\
\text { Waktu di Starbucks }\end{array}$ & $\begin{array}{c}\text { Frekuen } \\
\text { si }\end{array}$ & $\begin{array}{c}\text { Persen } \\
(\%)\end{array}$ \\
\hline Total & 390 & $100 \%$ \\
\hline
\end{tabular}

Bila dilihat dari frekuensi kedatangan, maka sebenarnya sebagian besar partisipan hanya datang sebanyak 1 hingga 2 kali dalam seminggu, sedangkan yang datang hingga 4 sampai 5 kali tidak begitu banyak. Hal ini menunjukkan sebagian besar partisipan dalam penelitian ini belum memiliki kebiasaan yang konsumtif untuk datang ke Starbucks secara berlebihan dalam waktu seminggu. Hasil lengkap dari frekuensi kedatangan dalam waktu seminggu dapat dilihat pada Tabel 3 berikut:

Tabel 3

Frekuensi Kedatangan ke Starbucks Selama Seminggu

\begin{tabular}{cccc}
\hline No & Kedatangan & Frekuensi & Persen (\%) \\
\hline 1. & 1 kali & 157 & $40.26 \%$ \\
2. & 2 kali & 134 & $34.36 \%$ \\
3. & 3 kali & 77 & $19.74 \%$ \\
4. & 4 kali & 18 & $4.62 \%$ \\
5. & 5 kali & 4 & $1.02 \%$ \\
\hline & Total & 390 & $100 \%$ \\
\hline
\end{tabular}

Sebelum melakukan pengujian hipotesis dengan menggunakan uji korelasi, peneliti melakukan uji asumsi terlebih dahulu. Uji asumsi yang peneliti gunakan adalah uji normalitas, dengan menggunakan One Sample Kolmogorov-
Smirnov. Hasil dari uji normalitas data ini adalah data pada variabel gaya hidup hedonisme terdistribusi normal ( $p=0,200>$ 0,05), data pada variabel harga diri tidak terdistribusi normal $(p=0,000<0,05)$, dan data pada kelima karakteristik kepribadian (openness to experience, conscientiousness, extraversion, agreeableness, neuroticism) juga tidak terdistribusi normal $(\mathrm{p}=0,000<0,05)$. Menurut Nisfianoor (2009), bila data tidak terdistribusi normal maka teknik analisis yang digunakan adalah teknik korelasi Spearman, sementara bila data terdistribusi normal maka yang digunakan adalah teknik korelasi Pearson. Dalam data penelitian ini karena data tidak terdistribusi normal maka yang digunakan adalah teknik korelasi Spearman. Berikut merupakan tabel yang merangkum gambaran harga diri, gaya hidup hedonisme, dan data pada kelima karakteristik kepribadian.

Tabel 4

Analisis Deskriptif Variabel

\begin{tabular}{cccc}
\hline Variabel & Min & Maks & Mean \\
\hline Harga diri & 1,67 & 4,00 & 2,85 \\
Gaya hidup & 1,27 & 3,37 & 2,50 \\
$\begin{array}{c}\text { Hedonisme } \\
\text { Openness to }\end{array}$ & 1,00 & 5,00 & 3,31 \\
$\begin{array}{c}\text { experience } \\
\text { Conscientiousness }\end{array}$ & 1,00 & 5,00 & 3,05 \\
Extraversion & 1,00 & 5,00 & 2,94 \\
\hline
\end{tabular}




\begin{tabular}{cccc}
\hline Variabel & Min & Maks & Mean \\
\hline Agreeableness & 1,50 & 5,00 & 3,41 \\
Neuroticism & 1,00 & 5,00 & 3,08 \\
\hline
\end{tabular}

Hasil analisis menunjukkan nilai harga diri berada dalam tingkatan kategori tinggi karena memiliki mean empirik yang lebih besar dari mean hipotetik yang menggunakan nilai tengah 2,5 pada skala 1-

4. Dengan demikian hal ini menunjukkan bahwa partisipan memiliki harga diri yang tinggi. Sementara itu, nilai pada gaya hidup hedonisme berada dalam tingkatan kategori sedang karena memiliki mean empirik yang sebanding dengan mean hipotetik yang menggunakan nilai tengah 2,5 pada skala 14. Hasil ini menunjukkan bahwa partisipan cenderung tidak memiliki gaya hidup hedonisme yang tinggi, namun gaya hidup hedonisme pada para partisipan juga tidak rendah. Hasil pada keempat karakteristik kepribadian (openness, conscientiousness, agreeableness, neuroticism) ditemukan bahwa keempat karakteristik kepribadian tersebut berada dalam kategori tinggi karena memiliki nilai mean empirik yang lebih besar dari mean hipotetik yang menggunakan nilai tengah 3 pada skala 1-5. Hasil ini menunjukkan bahwa keseluruhan partisipan dalam penelitian ini memiliki kepribadian yang terbuka terhadap pengalaman baru dan mau mencoba hal yang berbeda (openness to experience), kemudian partisipan juga memiliki kesadaran untuk melakukan segala sesuatu atau mempersiapkan sesuatu dengan baik (conscientiousness). Partisipan juga memiliki tipe hubungan yang hangat, mudah berteman, dan cenderung memiliki pandangan positif terhadap orang lain (agreeableness), namun partisipan secara keseluruhan juga memiliki kecenderungan untuk mudah memiliki perasaan negatif seperti cemas, marah, frustrasi, depresi dan kesepian (neuroticism).

Pengujian yang digunakan dalam penelitian ini adalah uji korelasi Spearman dengan melibatkan 8 variabel, yakni harga diri, gaya hidup hedonisme dan 5 karakteristik kepribadian (openness to experience, conscientiousness, extraversion, agreeableness, neuroticism). Hasil pengujian menunjukkan bahwa terdapat hubungan negatif yang signifikan antara harga diri dengan gaya hidup hedonisme $(p=0.003<$ 0,$\left.01 ; r=-0,150^{* *}\right)$ dan terdapat hubungan positif yang signifikan antara karakteristik kepribadian conscientiousness dengan gaya hidup hedonisme $(\mathrm{p}=0,025<0,05 ; \mathrm{r}=$ 0,113*). Pada hasil analisis korelasi juga ditemukan bahwa empat karakteristik kepribadian lainnya tidak memiliki 
hubungan signifikan dengan gaya hidup hedonisme, yakni: openness to experience $(\mathrm{p}=$ $0,458>0,05 ; \mathrm{r}=-0,038)$, extraversion $(\mathrm{p}=$ $0,941>0,05 ; \mathrm{r}=-0,004)$, agreeableness $(\mathrm{p}=$ $0,257>0,05 ; \mathrm{r}=-0,058)$, neuroticism $(\mathrm{p}=0,116$ $>0,05 ; \mathrm{r}=0,080$ )

\section{Diskusi}

Harga diri partisipan dalam penelitian ini cenderung tinggi, oleh karena itu para partisipan dalam penelitian ini memiliki kecenderungan untuk tidak
Partisipan dalam penelitian ini sendiri memiliki gaya hidup hedonisme yang berada dalam kategori sedang sehingga sebenarnya kecenderungan gaya hidup hedonisme pada para partisipan tidak sepenuhnya rendah. Salah satu penyebab mengapa harga diri memiliki hubungan yang signifikan dengan gaya hidup hedonisme dapat dijelaskan dalam hasil penelitian yang dilakukan oleh Dwizota, Dudek, Ludwikowska, dan Kowalski (2016) yang menemukan bahwa seseorang dengan

Tabel 5

Matriks Korelasi Antar Variabel

\begin{tabular}{|c|c|c|c|c|c|c|c|}
\hline & Openn & Consc & Extra & Agree & Neuro & Harga diri & $\begin{array}{l}\text { Gaya hidup } \\
\text { Hedonisme }\end{array}$ \\
\hline Openn & 1,000 & 0,011 & $0,535^{* *}$ & 0,010 & 0,069 & 0,096 & $-0,038$ \\
\hline Consc & 0,011 & 1,000 & 0,048 & $0,150^{* *}$ & $-0,093$ & $0,277^{* *}$ & $0,113^{*}$ \\
\hline Extra & $0,535^{* *}$ & 0,048 & 1,000 & $-0,016$ & $-0,151^{* *}$ & $0,187^{* *}$ & $-0,004$ \\
\hline Agree & 0,010 & $0,150^{* *}$ & $-0,016$ & 1,000 & $-0,112^{*}$ & 0,094 & $-0,058$ \\
\hline Neuro & 0,069 & $-0,093$ & $-0,151^{* *}$ & $-0,112^{*}$ & 1,000 & $-0,168^{* *}$ & 0,080 \\
\hline Harga diri & 0,096 & $0,277^{* *}$ & $0,187^{* *}$ & 0,094 & $-0,168^{* *}$ & 1,000 & $-0,150^{* *}$ \\
\hline $\begin{array}{l}\text { Gaya hidup } \\
\text { Hedonisme }\end{array}$ & $-0,038$ & $0,113^{*}$ & $-0,004$ & $-0,058$ & 0,080 & $-0,150^{* *}$ & 1,000 \\
\hline
\end{tabular}

mudah mengalami gaya hidup hedonisme.

Meskipun demikian, hubungan negatif yang signifikan yang ditemukan diantara harga diri dan gaya hidup hedonisme mengindikasikan bahwa semakin tinggi harga diri seseorang maka semakin rendah gaya hidup hedonisme yang dimilikinya. harga diri yang rendah akan lebih mudah mengadopsi nilai yang menekankan pada konformitas, kesenangan, dan kehidupan yang nyaman ketika dibandingkan dengan orang yang memiliki harga diri tinggi. Dalam penelitian tersebut (Dwizota, et al., 2016) dijelaskan bahwa seseorang dengan 
harga diri rendah cenderung lebih sensitif terhadap penolakan sosial, dan senantiasa mencari pengalaman yang menyenangkan. Hal ini dapat menjadi penyebab individu dengan harga diri rendah dapat lebih mudah mengalami gaya hidup hedonisme, namun ketika individu memiliki harga diri yang tinggi maka individu tersebut tidak mudah untuk mengikuti kebiasaan orang lain (konformitas) untuk mendapat pengakuan dari kelompok sosial ataupun mencari kesenangan dan kenyamanan secara berlebihan untuk merasa positif.

Penelitian yang dilakukan oleh Ksendzova, et al (2015) menemukan bahwa hedonisme dapat dibedakan menjadi valuebased hedonism, yaitu prinsip yang menilai tinggi kesenangan dibanding tujuan lain dan maladaptive-hedonism, yaitu prinsip yang menekankan pengorbanan dalam mengejar kesenangan dalam hidup hingga mempengaruhi kesejahteraan individu. Dalam penelitian tersebut (Ksendzova, et al., 2015) diketahui bahwa value-based hedonism memiliki hubungan signifikan yang negatif dengan conscientiousness dan agreeableness, sementara maladaptive hedonism berhubungan negatif secara signifikan dengan conscientiousness dan agreeableness, serta berhubungan positif secara signifikan dengan neuroticism. Pada penelitian ini penyebab tidak ditemukannya hasil yang serupa pada penelitian milik Ksendzova, et al (2015) kemungkinan disebabkan karena variabel gaya hidup hedonisme yang disusun dalam penelitian ini cenderung tidak mengutamakan nilai hedonisme dan hedonisme yang maladaptif, namun gaya hidup hedonisme dalam penelitian ini membahas pengukuran aktivitas, minat, dan pendapat yang utamanya diarahkan pada konsumsi produk Starbucks. Sementara pada penelitian milik Ksendzova et al (2015), nilai hedonisme diukur dengan skala value of pleasure yang mengukur kepentingan dalam melakukan aktivitas menyenangkan, sedangkan nilai hedonisme maladaptif diukur dengan skala buatan sendiri dalam penelitian yang mengukur pencarian kesenangan berlebihan hingga mengabaikan tanggung jawab. Oleh karena itu, gaya hidup hedonisme yang dikur dalam penelitian ini sebenarnya lebih cenderung ke arah gaya hidup hedonis yang berhubungan dengan kesukaan dan konsumsi produk Starbucks dan hal ini menyebabkan karakteristik kepribadian yang diukur memiliki hasil berbeda dengan penelitian sebelumnya.

Pada penelitian ini diperoleh data bahwa kepribadian conscientiousness 
berhubungan dengan gaya hidup hedonisme mahasiswa pengunjung Starbucks Jakarta. Hal ini mendukung hasil penelitian sebelumnya yang dilakukan oleh O'Connor, Conner, Jones, McMillan dan Ferguson (2009) yang meneliti hubungan kepribadian conscientiousness dengan konsumsi kafein, dimana pada penelitian tersebut ditemukan bahwa kepribadian conscientiousness dihubungkan dengan rendahnya konsumsi snack yang tinggi lemak dan lebih banyak konsumsi buah serta tingginya konsumsi kafein dan rokok (pada perokok) selama periode waktu 28 hari. Gaya hidup hedonisme dalam penelitian ini konteksnya berhubungan dengan konsumsi produk kopi Starbucks yang juga merupakan minuman mengandung kafein sehingga semakin tinggi kepribadian conscientiousness yang dimiliki oleh mahasiswa maka akan memicu tingginya konsumsi kafein pula pada mahasiswa tersebut. Salah satu ciri dari kepribadian conscientiousness adalah adanya rasa ingin melakukan segala sesuatu dengan baik, dan kecenderungan ini dapat mengarah pada perfeksionisme (Stoeber, Otto, \& Dalbert, 2009). Menurut Shafique, Gul dan Raseed (2017), perfeksionisme dapat menimbulkan stres pada individu karena perfeksionisme dapat menimbulkan rasa takut akan penilaian buruk dalam diri individu yang kemudian dapat memicu stres. Seseorang yang memiliki kecenderungan perfeksionisme kemudian akan dapat beralih pada konsumsi kopi karena kopi sendiri ditemukan dapat menurunkan tingkat stres yang dialami (Richard \& Smith, 2015). Selain itu, konsumsi kopi juga ditemukan dapat mempertahankan kemampuan kognitif dan fisik dalam melakukan suatu aktivitas (McLellan, Caldwell, \& Lieberman, 2016). Dengan demikian, ketika mahasiswa memiliki kecenderungan kepribadian dengan karakteristik conscientiousness yang tinggi maka mahasiswa tersebut memiliki kemungkinan mengkonsumsi kopi secara berlebihan dikarenakan kecenderungan perfeksionisme yang dimilikinya.

\section{Kesimpulan}

Penelitian ini menunjukkan bahwa terdapat hubungan yang signifikan antara harga diri dengan gaya hidup hedonisme mahasiswa pengunjung Starbucks Jakarta, dan terdapat hubungan yang signifikan antara conscientiousness dengan gaya hidup hedonisme mahasiswa. Karakteristik kepribadian conscientiousness yang tinggi menyebabkan mahasiswa sifat memiliki perfeksionisme dan membuat mahasiswa memiliki kecenderungan untuk 
mengkonsumsi kopi secara berlebihan. Selain itu, harga diri yang rendah pada mahasiswa memicu motivasi mengunjugi Starbucks bukan hanya karena konsumsi kopi saja, melainkan juga untuk mendapatkan pengakuan dan kepercayaan diri.

Saran untuk penelitian selanjutnya adalah meneliti faktor-faktor lain yang dapat mempengaruhi gaya hidup hedonisme selain dari faktor yang dibahas dalam penelitian ini. Saran untuk mahasiswa adalah agar dapat memiliki harga diri yang tinggi dan mengurangi kecenderungan perfeksionisme yang dimiliki. Hal ini dikarenakan bila mahasiswa terlalu cemas untuk mendapat pengakuan dari teman atau menghindari evaluasi negatif dari lingkungan sekitarnya maka mahasiswa akan lebih mudah jatuh dalam gaya hidup hedonisme.

\section{Kepustakaan}

Armstrong, G., \& Kotler, P. (2015). Marketing: An introduction (12 $2^{\text {th }}$ ed). Edinburg Gate, England: Pearson Education Limited.

Bella, A. (2019). Gerai starbucks terbesar kedua di dunia hadir di Bali. Diunduh dari http://marketeers.com/gerai-starbucksterbesar-kedua-di-dunia-hadir-di-bali/.

Blackwell, R. D., Miniard, P. W., Engel, J. F., Di-ching, P., Yasin, N. M., \& Hood, W. J. (2012). Consumer behavior. Lorong Chuan, Singapore: Cengage Learning Asia.
Dwizota, K., Dudek, A., Ludwikowska, K., \& Kowalski, D. (2016). Value preferences in individuals with low and high selfesteem. Curr Probl Psychiatry, 17(2): 97106. doi: 10.1515/cpp-2016-0011.

Farida (2019). Starbucks paling banyak gunakan kopi Indonesia. Diunduh dari https://www.arahdestinasi.com/travelne ws/read/594/starbuck_paling_banyak_gu nakan_kopi_indonesia.

Hadijah, S. (2017). Kopi Indonesia terus meningkat dan jadi gaya hidup baru yang populer. Diunduh dari https://www.cermati.com/artikel/kopiindonesia-terus-meningkat-dan-jadigaya-hidup-baru-yang-populer.

Hartati, M. S., \& Setyawan, I. (2010). Correlation among self-esteem with a tencency hedonist lifestyle of students at diponegoro university. Naskah tidak dipublikasikan, Fakultas Psikologi, Universitas Diponegoro. Diunduh dari http://eprints.undip.ac.id/24778/.

Herlyana, E. (2012). Fenomena coffee shop sebagai gejala gaya hidup baru kaum muda. Thaqafiyyat, 13(1), 188-204. Diunduh dari http://ejournal.uinsuka.ac.id/adab/thaqafiyyat/article/view/ $43 / 42$.

Idris, M. (2017). Digemari kaum milenial, konsumsi kopi RI tumbuh 8\%/tahun. Diunduh dari

https://finance.detik.com/beritaekonomi-bisnis/d-3497320/digemarikaum-milenial-konsumsi-kopi-ritumbuh-8tahun.

Maharani, S. (2018). Fenomena 'demam' coffee shop di Indonesia. Diunduh dari https://kumparan.com/@kumparanfood/f enomena-mewabahnya-demam-coffeeshop-di-indonesia.

Nisfiannoor, M. (2009). Pendekatan statistika modern untuk ilmu sosial. Jakarta: Salemba Humanika.

Ng, I. P. Y. (2015). Starbucks: Catalyst to hedonism among students today? 
Working Paper Series Faculty of Social Sciences, 81. Diunduh dari https://www.academia.edu/27102457/Sta rbucks_Catalyst_to_Hedonism_among_S tudents_Today.

Ksendzova, M., Iyer, R., Hill, G., Wojcik, S. P., \& Howell, R. T. (2015). The portrait of a hedonist: The personality and ethics behind the value and maladaptive pursuit of pleasure. Personality and Individual Differences, 79(2015): 68-74. Diunduh dari http://seanwojcik.com/Ksendova\%20Iyer \%20Hill\%20Wojcik\%20\&\%20Howell\%20 2015.pdf.

Laucereno, S. F. (2018). 150 gerai di Starbucks mau tutup, kok di RI tambah 60? Diunduh dari https://finance.detik.com/industri/d4076111/150-gerai-starbucks-di-as-maututup-kok-di-ri-tambah-60.

McLellan, T. M., Caldwell, J. A., \& Lieberman, H. R. (2016). A review of caffeine's effects on cognitive, physical and occupational performance. Neuroscience \& Biobehavioral Reviews, 71, 294-312. doi:10.1016/j.neubiorev.2016.09.001.

O'Connor, D. B., Conner, M., Jones, F., McMillan, B., \& Ferguson, E. (2009). Exploring the benefits of conscientiousness: An investigation of the role of daily stressors and health behaviors. Ann Behav Med, 37(2): 184-196. Diunduh dari https://www.ncbi.nlm.nih.gov/pubmed/1 9322619.

Prodjo, W. A. (2016). Tren 2017, kedai artisan kopi akan menjamur. Diunduh dari https://travel.kompas.com/read/2016/12/1 6/190800927/tren.2017.kedai.artisan.kopi.a kan.menjamur.

Rammstedt, B., \& John, O. P. (2006). Measuring personality in one minute or less: A 10-item short version of the big five inventory in english and german. Journal of Research in Personality, 41(1): 203-212. Diunduh dari https://www.sciencedirect.com/science/a rticle/abs/pii/S0092656606000195.

Richards, G., \& Smith, A. (2015). Caffeine consumption and self-assessed stress, anxiety, and depression in secondary school children. Journal of Psychopharmacology (Oxford, England), 29(12), 1236-1247. doi:10.1177/0269881115612404.

Rikang, R. W., \& Dharma, P. (2014). Orang Indonesia makin gemar minum kopi. Diunduh dari https://bisnis.tempo.co/read/589168/oran g-indonesia-makin-gemar-minumkopi/full\&view $=$ ok.

Rosenberg, M. (1965). Society and the adolescent self-image. Princeton, NJ: Princeton University Press.

Shafique, N., Gul, S., \& Raseed, S. (2017). Perfectionism and perceived stress: The role of fear of negative evaluation. International Journal of Mental Health, 46(4),

312-326. doi:10.1080/00207411.2017.1345046.

Stoeber, J., Otto, K., \& Dalbert, C. (2009). Perfectionism and the big five: conscientiousness predicts longitudinal increases in self-oriented perfectionism. Personality and Individual Differences, 47(4), 363-368. doi:10.1016/j.paid.2009.04.004.

Wijayanti. A., \& Astiti, P. D. (2017). Hubungan antara konsep diri dengan perilaku konsumtif remaja di kota Denpasar. Jurnal Psikologi Udayana, 4(1), 41-49. Diunduh dari https://simdos.unud.ac.id/uploads/file_p enelitian_1_dir/fa62f42dd31983bcb06c07 bb1867e94b.pdf. 